Folia phoniat. 1984;36:I-IV

\title{
Contents, Vol. 36, 1984
}

\section{No. 1 Original Paper}

Phonographic Relationship between Pitch and Intensity of the Human Voice

Komiyama, S.; Watanabe, H.; Ryu, S 1

Speech, Language and Communication Disorders of the Multiply Handicapped

Schiefelbusch, R.L 8

Sound Spectrographic Analysis of the Voice of Patients with Glottic Carcinomas

Mook Yoon, K.; Kakita, Y.; Hirano, M

Interaction of Experimentally Elicited Auricular Cough with Voluntary Phonation

Geoffrey, V.C.; Bernthal, J.E.; Bertorini, T.E.; Bosma, J.F 31

On the Meaning of 'Language Delay'

Liles, B.Z.; Watt, J.H 40

IALPNews 49

No. 2 Original Paper

Quantitative Study of Whisper

Monoson, P.; Zemlin, W.R 53

Empirische Untersuchung der sozialen Situation von Aphasikern

Joussen, K.; Pascher, W 66

Stimmlippenlähmungen in der phoniatrischen Praxis

Wendler, J.; Vollprecht, I.; Nötzel, M.; Klein, C; Fuchs, R 74

Phoniatric Disturbances in Patients after Partial Tongue Resection for Malignant Neo

plasms

Pruszewicz, A.; Kruk-Zagajewska, A 84

Listening Preferences for Music as a Function of Age

Tolhurst, G.C.; Hollien, H.; Leeper, L 93

IALPNews 101

No. 3 Original Paper

Relationships between Electroglottograph, Speech, and Vocal Cord Contact

Childers, D.G.; Smith, A.M.; Moore, G.P 105

Beeinflussen Stimmbelastung und Stimmgewohnheiten den Stimmwechselabschluss?

Ackermann, R 119

Contents

III

Mechanism of Dysphonia in Melkersson-Rosenthal Syndrome

Vecerina, S.; Jusic, A.; Subotic, R 122

Weight Measurements of Infant and Adult Intrinsic Laryngeal Muscles

Kahane, J.C.; Kahn, A.R 129

Faktoren zur Effektivitätsbestimmung der Stimmfunktionstherapie

Pfau, E.-M 134

Fundamental Frequency Contours of Stutterers' Vowels following Fluent Stop Consonant 
Productions

Healey, E.C 145

Book Review 152

IALPNews 153

No. 4 Original Paper

Some Spectral Characteristics of Airflow Signals Associated with Oral Reading

Horii, Y 157

Physiologic and Perceptual Effects of Induced Anterior Open Bite

Warren, D.W.; Allen, G.; King, H.A 164

Speaker Race Identification of Selected Adult North American Indians

Moon, J.B.; Leeper, H.A., Jr 174

Effect of Speaking Rate on Nasal Airflows in Hearing-Impaired Speakers

Gilbert, H.R.; Hoodin, R.B 183

Perturbation Analysis of Normal and Pathologic Larynges

Zyski, B.J.; Bull, G.L.; McDonald, W.E.; Johns, M.E 190

Comparison of the Sensitivity of Two Psychological Scaling Methods Employed in the Rat ing of Rate and Duration Characteristics of Esophageal Speakers

Hein, S.L.; Beasley, D.S 199

Prof. Sedlácek's Jubilee 206

IALPNews 209

No. 5 Original Paper

Emotionale Determinanten der Stimmfunktionstherapie

Pfau, E.-M 213

Cry Score - an Aid in Infant Diagnosis

Michelsson, K.; Raes, J.; Rinne, A 219

Breath Management in Repeated Vocal Onset

Schutte, H.K.; Miller, R 225

Fine Morphology of the Posterior Cricoarytenoid Muscle

Zemlin, W.R.; Davis, P.; Gaza, C 233

Oberflächen-Elektromyographie zur Untersuchung der Stimmfunktion

Jacoby, P.; Rabine, E.; Rohmert, G.; Rohmert, W.; Timm, C; Zipp, P

241

Funktionelle Stimmstörung bei Sängern in der sonagraphischen Analyse

Frank, F 249

IALPNews 257

IV

Contents

No. 6 Original Paper

Sensory Integrative Therapy and Speech Therapy for Improving the Perceptual Motor Skills and Speech Articulation of a Dyspractic Boy

Jaroma, M.; Danner, P.; Koivuniemi, E 261

Efficiency of Professional Singing Voices in Terms of Energy Ratio

Schutte, H.K $\quad .267$

Zur Verteilung und funktionellen Auswirkung von Paresen der Stimmlippenbewegungs- und -spannmuskulatur anhand elektromyographischer Untersuchungen

Pahn, J.; Dettmann, R.; Sram, F 273

Elektromyographie bei funktionellen Dysphonien mit Hilfe der Oberflächenelektrode 
Lasiovka, M.; Sram, F.; Sedlácek, K 284

Resonance Balance in Register Categories of the Singing Voice: A Spectral Analysis Study Schutte, H.K.; Miller, R 289

The Frequency of Occurrence of Foramen Thyroideum in the Human Larynx

Zemlin, W.R.; Simmon, A.; Hammel, D 296

Book Reviews 301

IALPNews 304

Author Index 308

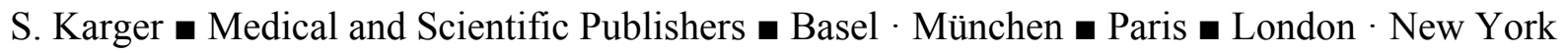
- Tokyo a Sydney

All rights reserved.

No part of this publication may be translated into other (C) Copyright 1984 by

languages, reproduced or utilized in any form or by any $\quad$ S. Karger AG, P.O. Box, CH-4009

Basel (Switzerland)

means, electronic or mechanical, including photocopy- $\quad$ Printed in Switzerland by Thür AG

Oí setdruck, Pratteln

ing, recording, microcopying, or by any information storage and retrieval system, without permission in writing from the publisher or, in the case of photocopying, direct payment of a specified fee to the Copyright Clearance Center (see 'Information for Readers and Subscribers'). 